\title{
огляди
}

UDC 612.017.1

\section{BIOLOGICAL AND IMMUNOCHEMICAL PROPERTIES OF POLYREACTIVE IMMUNOGLOBULINS}

\author{
S. A. BOBROVNIK, M. A. DEMCHENKO, S. V. KOMISARENKO \\ Palladin Institute of Biochemistry, National Academy of Sciences of Ukraine, Kyiv; \\ e-mail: s-bobrov@bk.ru
}

A previously unknown phenomenon of acquired polyreactivity of serum immunoglobulins, which were subject to the effect of concentrated solutions of chaotropic ions, such as KSCN (3.0-5.0 M), low/high pH ( $p H$ 2.2-3.0), or heating to $58-60^{\circ} \mathrm{C}$, was originally described by the authors in 1990. Eleven years after that, similar data were published by J. P. Bouvet et al.(2001), which confirmed completely our results concerning the influence of either chaotropic ions or drastic shift of $\mathrm{pH}$ on polyreactive properties of immunoglobulins. Our further investigations $(1993,1995,1998)$ of polyreactive serum immunoglobulins (PRIG) properties have revealed that the mechanism of nonspecific interaction between PRIG and antigens much differs from the mechanism of interaction between specific antibodies and corresponding antigens. Later we have shown that the increase in PRIG reactivity could be induced in vivo (1999) and PRIG are one of serum components of human or animal sera. Then, it could be suggested that PRIG may perform certain biological functions. Studying PRIG's effect on the phagocytosis of microbes or on the tumor growth (S. A. Bobrovnik et al., 1995, 1998) have revealed that PRIG may play a certain role in protecting the body from infections and probably may influence the development of various pathological processes. Recently we also found (S. A. Bobrovnik et al., 2014) that IgG PRIG content significantly increases in aged people. These data demonstrate that further investigations of PRIG's immunochemical properties and study of their biological role in organism protection from various diseases is very important.

Key words: polyreactive immunoglobulins, natural antibodies, antigens, specificity, affinity, avidity.

\section{Detection of polyreactive immunoglobulins}

The phenomenon of immunoglobulin polyreactivity was first detected by the authors when studying the content of immune complexes in animal serum. It has been established that the animal sera, treated with solutions of chaotropic salts $(3.0-5.0 \mathrm{M}$ solution of $\mathrm{KSCN}$ ) or acidified to $\mathrm{pH} 2.0-2.5$ with the aim to dissociate the supposed immune complexes, acquire the ability to bind with various antigens several times stronger than initial sera [1, 2]. Since the aim of sera treatment by KSCN solution or their acidifying to $\mathrm{pH} 2.0-2.5$ was the destruction of the supposed immune complexes, the revealed intensification of sera reactivity after such treatments seemed rather logical and connected with dissociation of immune complexes, i.e., with unblocking of antibodies available in the serum which had been blocked by the antigen.
But we have soon established that preliminary removal of immune complexes from sera (by their precipitation with polyethylene glycol) has practically no influence on their ability "to become activated" under the above effects. Moreover, not only human and animal sera had the property "to become activated", but also immunoglobulin fractions isolated from them (Fig. 1), which seemed to contain almost no immune complexes [1,2]. Acidification (to $\mathrm{pH}$ 2.0-3.0) or alkalization (to $\mathrm{pH} 11.0-12.0$ ) as well as heating of sera during $10-20 \mathrm{~min}$ at $58-60{ }^{\circ} \mathrm{C}$ also led to such "activation". It has become clear that we deal here with the phenomenon that has never been described in the literature.

At that time it was extremely interesting and unclear for us that the antibodies activated in this manner possessed practically no specificity and were able to react almost in the same way with absolutely 
various antigens which were serologically unallied. In this connection we called these antibodies "polyspecific" in our first works. Later immunoglobulins activated in this way and then similarly treated monoclonal antibodies which had lost their specificity were called polyreactive immunoglobulins (PRIG). Initially, the original cause of the detected polyspecificity of PRIG was not clear and could be explained in two different ways:

a) The studied samples of "activated" sera contain great quantity of various antibodies and owing to this can react with different antigens.

b) Each molecule of "activated" PRIG is able to bind nonspecifically to different, serologically unallied antigens.

We succeeded in solving this problem in the very beginning of the investigations $[1,2]$ in the following way. We performed experiments where studied the polyreactive samples of antibodies not only for binding ability to antigens adsorbed on plates, but also for inhibiting PRIG by soluble antigens as well as by those immobilized on the plate and by serologically foreign antigens. Since PRIG binding with the antigen immobilized on the plate could be blocked with almost the same efficiency by different soluble antigens, and the latter could be both serologically similar and different to immobilized antigen, and it became evident that PRIG do not consist of the great number of antibodies, each of them being specific to its antigen, but vice versa, each separate PRIG molecule can bind to different antigens [1].

This conclusion was also confirmed in other experiments [2]; it was shown that PRIG eluted from the column, on which a certain antigen A was immobilized, were further able to combine not only with the same antigen A, but also with other, serologically unallied antigens B, C, etc., and approximately with the same efficiency as to antigen A (Fig. 2). Consequently, the above experiments have unambiguously demonstrated that the interaction of PRIG and various unallied antigens is absolutely nonspecific, and this nonspecificity is connected with just a small set of various PRIG molecules, but each of PRIG molecules possesses this nonspecificity. Meantime, the cause of this PRIG nonspecificity had not been clear for us for a long period of time, and only after the mechanism of PRIG binding to antigens had been found out, we succeeded in solving this problem.

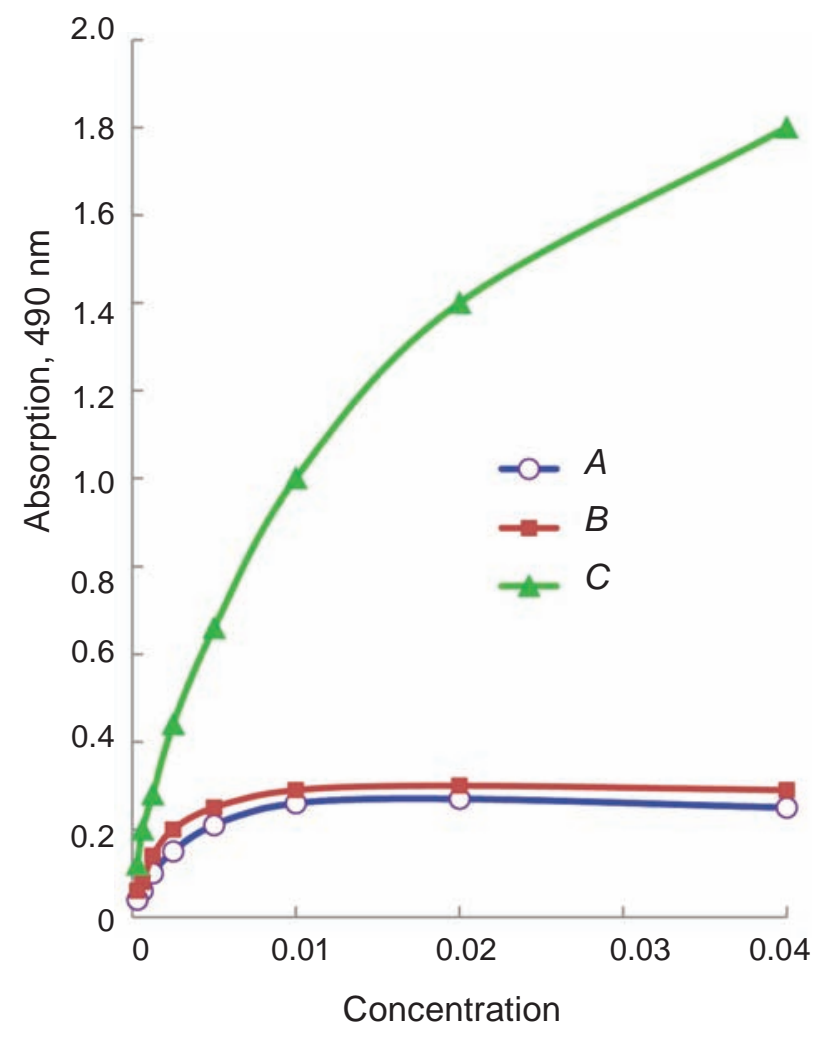

Fig. 1. ELISA titration of intact murine serum (A), its immunoglobulin fraction (B), and titration after its treatment with 3.5 M KSCN (C) on ovalbumin immobilized on the plate

\section{Mechanism of enhancing PRIG activity}

One of the questions concerning the discovered phenomenon of induced polyreactivity of immunoglobulins was the question of the cause of a considerable increase of their immunoglobulin polyreactivity in respect of various antigens as an effect of 3.0-5/0 KSCN, sharp shift of $\mathrm{pH}$ or heating to $58-60{ }^{\circ} \mathrm{C}$. A suggestion that antibodies of various specificity, which are blocked by corresponding antigens, are always available among the pool of immunoglobulins seemed the most simple and logical explanation. Then these antibodies are unblocked as a result of the above effects, and, correspondingly, their reactivity in respect of antigens considerably increases. Another explanation of this phenomenon was a supposition on the change of conformation of immunoglobulin molecules under the effect of the above reagents; as a result they acquire polyreactive properties.

As was shown experimentally, the first of the above explanations was incorrect. Firstly, as it was 
said above, we established that PRIG, obtained as a result of treatment of serum immunoglobulins by chaotropic ions or low/high $\mathrm{pH}$, do not consist of separate pools of antibodies, each of them being specific only for a certain antigen. Instead, they consist of molecules each of which is able to bind nonspecifically to different antigens.

Secondly, we have performed experiments trying to detect antigens that could dissociate from the supposed complexes with serum antibodies in the process of transformation of the latter into PRIG [12]. In these experiments the purified fraction of immunoglobulins was treated by $3.5 \mathrm{M} \mathrm{KSCN}$ solution at $25{ }^{\circ} \mathrm{C}$ during $15 \mathrm{~min}$, and then the obtained mixture was fractionated on Sephadex G75 column that allowed the separation of high-molecular immuniglobulins, low-molecular KSCN salts and expected dissociable antigens of unknown molecular weight. No blocking antigens were detected as a result of such fractionation of the studied mixture of immunoglobulins and KSCN [12]. Since we have not succeeded in detecting antigens which could, owing to their separation from immunoglobulins, lead to considerable enhancement of reactivity of the latter, the hypothesis of unblocking of antibodies was called into question for the second time.

And, thirdly, we succeeded in demonstrating that most highly specific monoclonal antibodies (as a result of their treatment with 3.5-4.0 M KSCN so- lution or acidification to $\mathrm{pH} 2.3-2.5$ at $25^{\circ} \mathrm{C}$ ) lose their specificity and acquire polyreactive properties (Fig. 3). Hence follows the conclusion that serum immunoglobulins which, as is known, are a mixture of numerous antibody clones specific for various antigens can acquire polyreactive properties under the effect of indicated actions. [13]. Owing to data obtained it has become evident that the main cause of enhancement of the ability of serum immunoglobulins to bind nonspecifically to antigens (after immunoglobulins treatment by 3.5-4.0 M KSCN or $\mathrm{pH} 2.3-2.5)$ is the change of molecules conformation, and as a result there occurs transformation of hitherto specific serum antibodies into nonspecific PRIG.

In this connection there arose the question: which part of immunoglobulin molecule in the process of transformation into PRIG is subject to structural changes. As is known, the molecules of antibodies consist of three parts: two Fab-domains responsible for binding with antigens and one $\mathrm{Fc}$-domain with the sites of binding to serum complement and to Fc-receptors of various cells, this domain also has the sites of binding to staphylococcus protein A. Our hypothesis that Fab-domains of immunoglobulins above all are subjected to structural changes in the process of transformation into PRIG, when Fcdomain stays practically intact, was confirmed in corresponding experiments. It has been established that PRIG can efficiently opsonize bacterial cells [9]
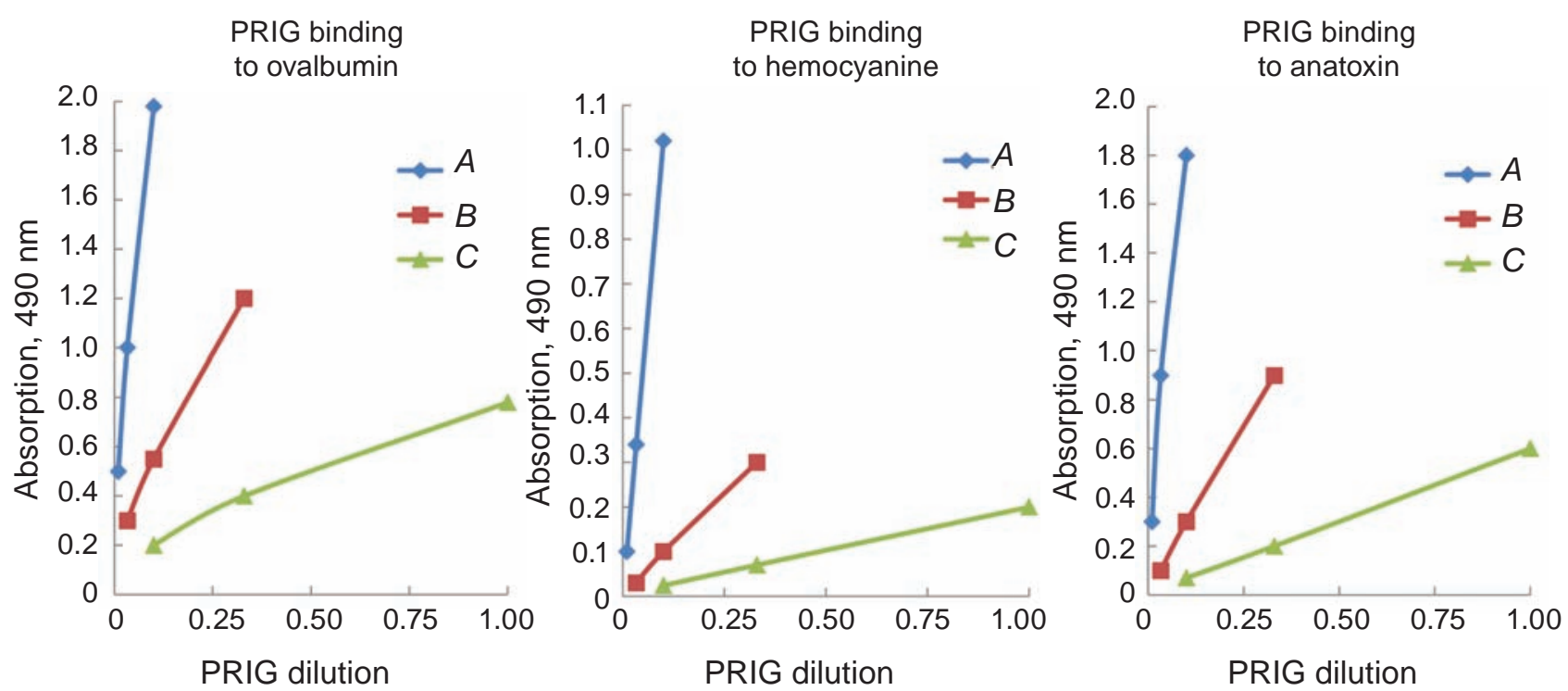

Fig. 2. PRIG binding to ovalbumin, keyhole limpet hemocyanine and staphylococcus anatoxin immobilized on plates. A - initial PRIG sample; B - PRIG sample eluted from the column with immobilized keyhole limpet hemocyanine; $C$ - PRIG sample eluted from the column with immobilized staphylococcus anatoxin 
that evidences for the absence of structure changes at their sites of binding to Fc-receptors. Besides, it has been shown that PRIG can fix both the complement and staphylococcus protein A [14]. All these data confirm our hypothesis that the transformation of immunoglobulins into PRIG mainly leads to the change of properties of Fab-domains responsible for binding to antigens, but it only slightly affects the conformation of Fc-domain of immunoglobulins which is responsible for the effector properties of antibodies [14].

\section{Mechanism of PRIG binding to antigens}

Study of the effect of various factors on the process of nonspecific binding of PRIG to antigens has led to the deciphering of the mechanism of PRIG-antigen interaction. Initially we investigated the effect of various physico-chemical conditions on PRIG binding to antigens adsorbed on the plates. In particular, we tested some salt solutions of different concentration, $\mathrm{pH}$ solutions, temperature. We also tried to estimate the affinity of PRIG binding to antigens $[6,7]$. However, the obtained data did not allow establishing the mechanism of PRIG-antigen interaction, since all of them, except for the temperature effect, gave relatively little information on differences between PRIG and specific antibodies in respect of the mechanism of their binding to antigens. And the fact that the temperature elevation up to physiological values $\left(30-37^{\circ} \mathrm{C}\right)$ is exceptionally
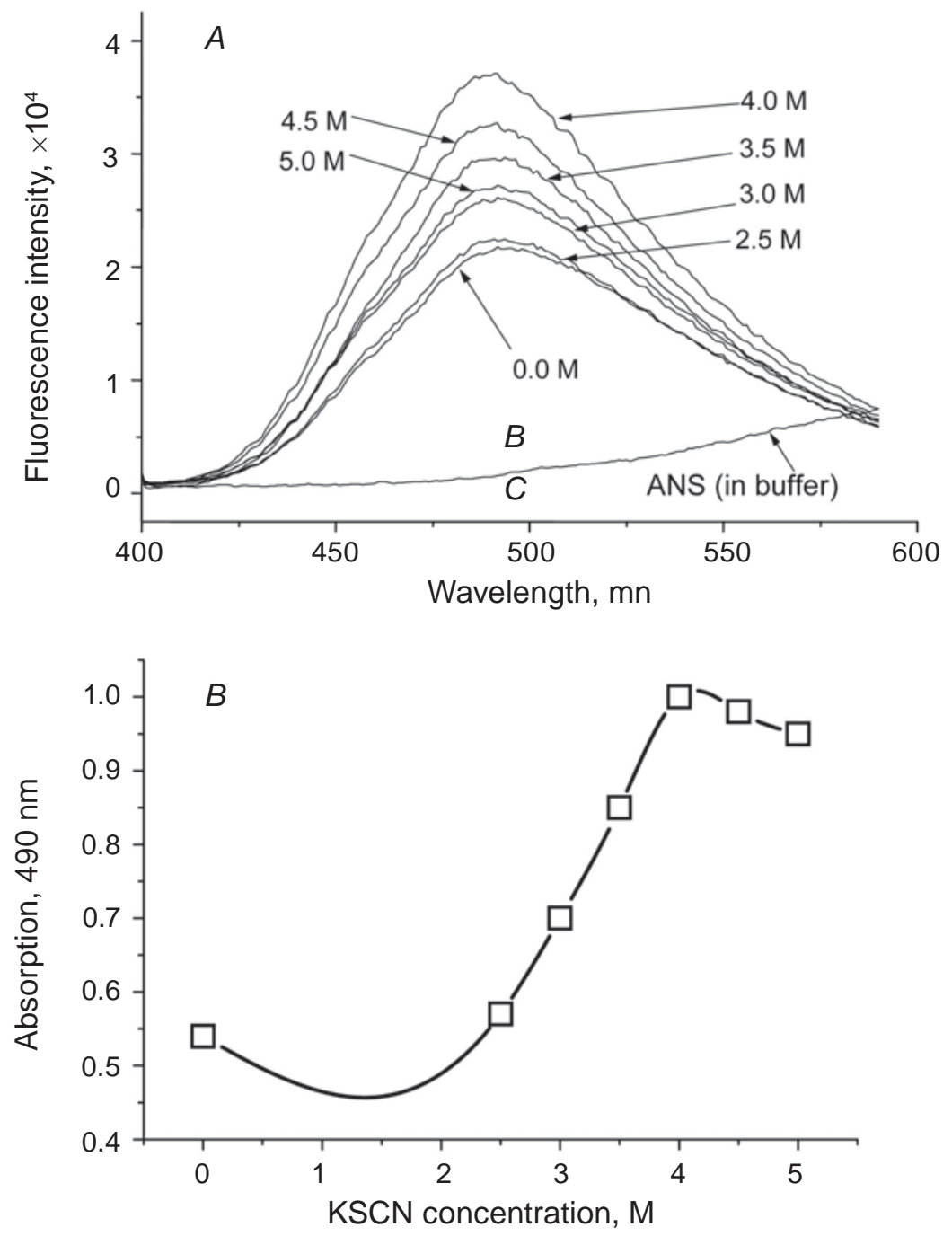

Fig. 3. A - ANS binding to bovine serum immunoglobulins preliminarily treated with KSCN solutions of various concentration (from 2.5 to $5.0 \mathrm{M}$ ); B - binding of the same samples of bovine serum preliminarily treated with KSCN solutions of various concentration (from 2.5 to $5.0 \mathrm{M}$ ) to bovine serum albumin adsorbed on the plate 
important for successful interaction of PRIG with antibodies, whereas the same temperatures did not influence considerably the binding of specific antibodies to antigens, are in good agreement with the later established mechanism of the PRIG-antigen reaction.

Note that the cause of PRIG nonspecificity (or low specificity of so called natural antibodies (NAb)) was interesting not only for us but also for other researchers that detected both serum [15-18] and monoclonal antibodies cross-reacting with different antigens [18-20]. This nonspecificity is often explained by the fact that it is primarily connected with high flexibility (and, as a result, high mobility) of polypeptide chain of antibodies located in their binding site to antigens $[1,21-25]$. It was supposed that this causes the adjustment of the structures of surfaces of two interacting molecules which become complementary. The idea of importance of high mobility of polypeptide chain in PRIG molecules has not lost its attractiveness for our model of PRIG interaction with antigens as well, but the main cause of their mutual affinity in this model has become somewhat different.

The fact (revealed by the present authors), that immunoglobulins transformation into PRIG leads to acquisition by the latter of a considerably higher affinity to hydrophobic materials, served as the basic one in establishing the mechanism of PRIG binding to antigens. In particular, PRIG are able to be adsorbed much more efficiently on the surface of immunologic plates than original intact immunoglobulins which were not subjected to transformation into PRIG. In this connection there arose the idea that the basic factor determining unspecific binding of PRIG to unallied antigens, may be their mutual hydrophobic interaction. The experiments performed in this line have convincinly confirmed our idea.

As is known the binding of specific antibodies with the corresponding antigens mainly depends on electrostatic (Coulomb) forces, on Van der Waals forces and, additionally, on hydrophobic effect [26-28], the first two types playing the main part. Since the above forces, especially Van der Waals ones, increase considerably with a decrease of the distance between interacting surfaces, it was evident that high affinity of the antigen-antibody reaction requires as high complementarity of surfaces of reacting macromolecules as possible. That's why it is believed that the basic models of antibodies binding to antigens are the key-lock model or the model of induced fitting of antibody and antigen structures. The former implies that the forms of interacting surfaces of antibody and antigen fit each other as the key fits the lock, and the latter model supposes that conformation of interacting molecules may change inconsiderably in the process of their interaction, and as a result they become even more complementary between themselves.

Our data suggested that the intermolecular hydrophobic interaction is of basic importance in the case of PRIG unspecific binding to antigens [29, 30]. This is evidenced by the following. Firstly, as noted above, the transformation of immunoglobulins into PRIG is accompanied by enhancing their ability to bind to hydrophobic materials, for example, to the surface of polysterene plates performed for immunologic investigations.

Another rather popular test for hydrophobicity extent of the studied protein macromolecules is spectrofluorometric estimation of the molecules ability to bind 8-amino-1-naphthol-5-sulphoacid (ANS). This test has helped us to show [30] that the ability to ANS binding, and, consequently, the number of hydrophobic sites on the surface of immunoglobulins considerably increases as a result of their transformation into PRIG (Fig. 3, A). Therewith we can observe correlation between the ability of PRIG molecules to bind ANS and the PRIG reactivity in respect of the antigens immobilized on plates (Fig. 3, $B)$. These data are confirmed by the conclusion on considerable increase of PRIG ability to hydrophobic interaction compared with intact molecules of immunoglobulins and on correlation of PRIG reactivity with the hydrophobicity extent of its molecular surfaces.

Secondly, such low-molecular substances as twin 20 or ANS, which are capable to bind to hydrophobic sites of protein molecules and, as a result, to screen them, slightly influence the binding of specific antibodies to antigens, but in return such substances extremely efficiently suppress the unspecific binding of PRIG (Fig. 4. $A$ and $B$ ) [30]. Thus, this test also evidences for the necessity of hydrophobic interaction for successful binding of PRIG to antigens.

And thirdly, we have revealed that thermal denaturation of protein molecules used as antigens makes these molecules being absorbed on immunologic plates and exposing the great number of hydrophobic sites on their surface to bind PRIG much more efficiently than the original intact molecules 

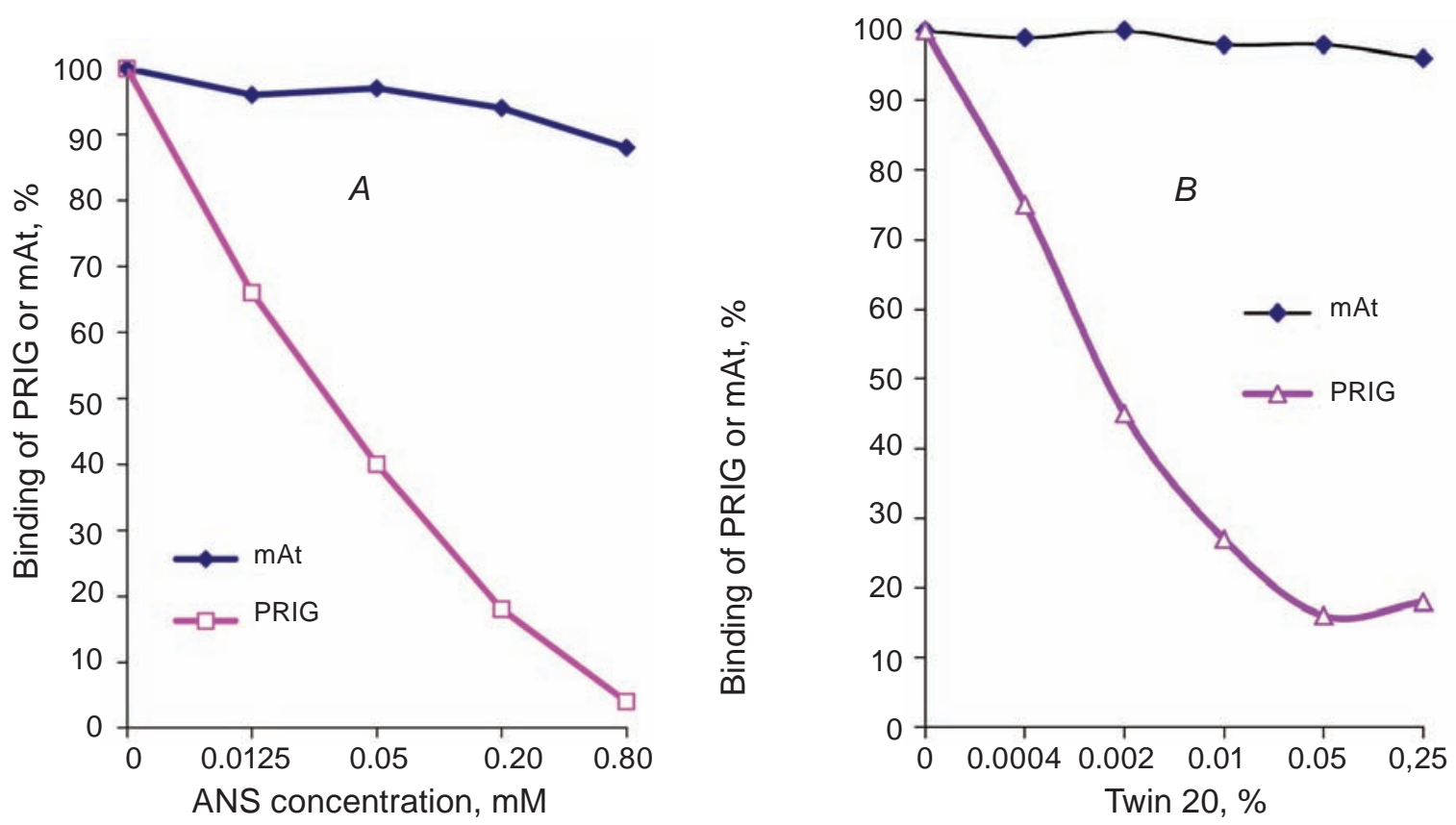

Fig. 4. Supressing of PRIG binding to antigen coupled to the plate with various concentrations of ANS (A) or Tween $20(B)$ and the absence of influence of these reagents on binding of specific $m A b$ with the same antigen

of the antigen. Thus, the hydrophobic interaction in the reaction of PRIG binding to antigens may be considered convincinly proved and, as a consequence, the basic mechanism of unspecific interaction of PRIG with various antigens is established $[29,30]$.

\section{Increase of PRIG activity in vivo}

It is evident that PRIG possess the whole number of properties which permit distinguishing them from specific antibodies. At the same time it remains unclear whether it is practically possible to increase essentially the serum PRIG activity in vivo, or this process may be realized only in the experiment in vitro. Since it is quite obvious that neither high concentrations of chaotropic ions, nor abrupt shifts of $\mathrm{pH}$ or heating to $58-60^{\circ} \mathrm{C}$ may be reached in vivo, there arises a question on the search of such conditions, which could exist in vivo, and therewith serum immunoglobulins were able to transform into PRIG.

As it turned out, the so-called reactive oxygen species (ROS) (including hydrogen peroxide $\left(\mathrm{H}_{2} \mathrm{O}_{2}\right)$, superoxide radical $\left(\mathrm{O}^{-}\right)$, or hydroxyl radical $\left(\mathrm{OH}^{\circ}\right)$ ) may be the factor meeting the above requirements. We have established [8] that (ROS) not only can induce the transformation of specific monoclonal antibodies into PRIG or considerably increase activity of serum immunoglobulins, but also the fact that they essentially exceed such physicochemical factors as chaotropic ions, low/high $\mathrm{pH}$ or heating to $58-60{ }^{\circ} \mathrm{C}$ indices this. For example, a mixture of erythrocyte lisate and $\mathrm{H}_{2} \mathrm{O}_{2}$ (being a source of ROS) induces to considerable extent the transformation of serum immunoglobulins into PRIG (Fig. 5) [8]. The same effect on the transformation of serum immunoglobulins into PRIG (Fig. 6, A) or mAt (Fig. 6, B) has another source of ROS that is the mixture of EDTA and the variable-valence metal salts, for example, $\mathrm{FeSO}_{4}$.

The fact that ROS are the factor which causes the antibodies transformation into PRIG is also evidenced by the fact that the substances capable of neutralizing ROS (manitol, sodium azide, or $\mathrm{NaHCO}_{3}$ ) efficiently suppress this process. Thus, not only chaotropic ions, abrupt shift of $\mathrm{pH}$ or high temperatures $\left(56-60{ }^{\circ} \mathrm{C}\right)$, but also ROS can essentially increase PRIG activity. In addition it should be noted that ethanol solution (optimal concentration 30-40\%) at temperature $37{ }^{\circ} \mathrm{C}$ as well as some other organic solvents, e. g., 40-80\% solution of dimethylsulphoxide can transform immunoglobulins into PRIG [34].

Taking into account that ROS are able to cause the antibodies transformation into PRIG is of great importance, since, it is known, that ROS can be produced in vivo, for example, in inflammation sites or under ischemia/reperfusion of muscles $[35,36]$. 


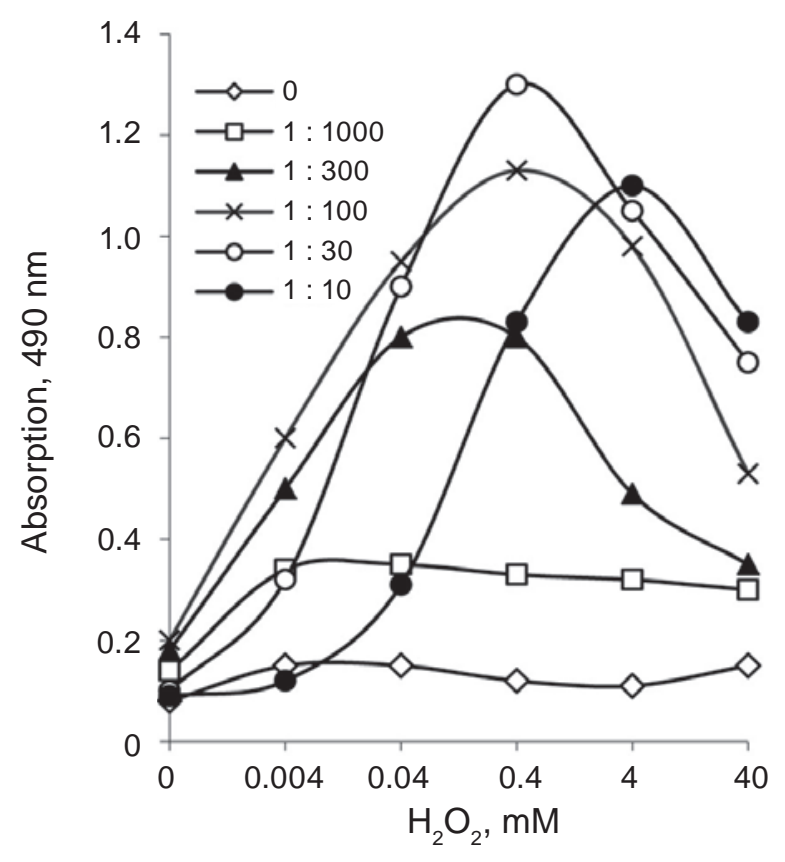

Fig. 5. Effect of a mixture of various dilutions of erythrocyte lysate and hydrogen peroxide on the ability of serum immunoglobulins to bind to immobilized antigens
Consequently, these facts evidence that at least the increase of PRIG activity may likely occur under certain conditions not only in vitro, but also in vivo. To find out whether PRIG activity is able to be increased in vivo and whether the transformation of specific $\mathrm{mAb}$ proceeds in PRIG is possible we have performed the following experiments.

Some mice were administered intramuscularly with EDTA and $\mathrm{FeSO}_{4}$ mixture, others with ethanol diluted to $40 \%$ in physiological $\mathrm{NaCl}$ solution, the ischemia/reperfusion of the hind limb muscles was performed in the third group of animals. An inconsiderable increase of PRIG activity in vivo occurs in all these cases, and the formed PRIG may be detected with the help of immunofluorescent and histochemical methods not only in the blood flow of animals but also attached to the vascular walls (Fig. 7) [34]. Thus, we have established that the transformation of antibodies into PRIG in vivo is possible under certain conditions. Therefore there arises the question: can PRIG play any role in organism protection or, on the contrary, favor development of certain
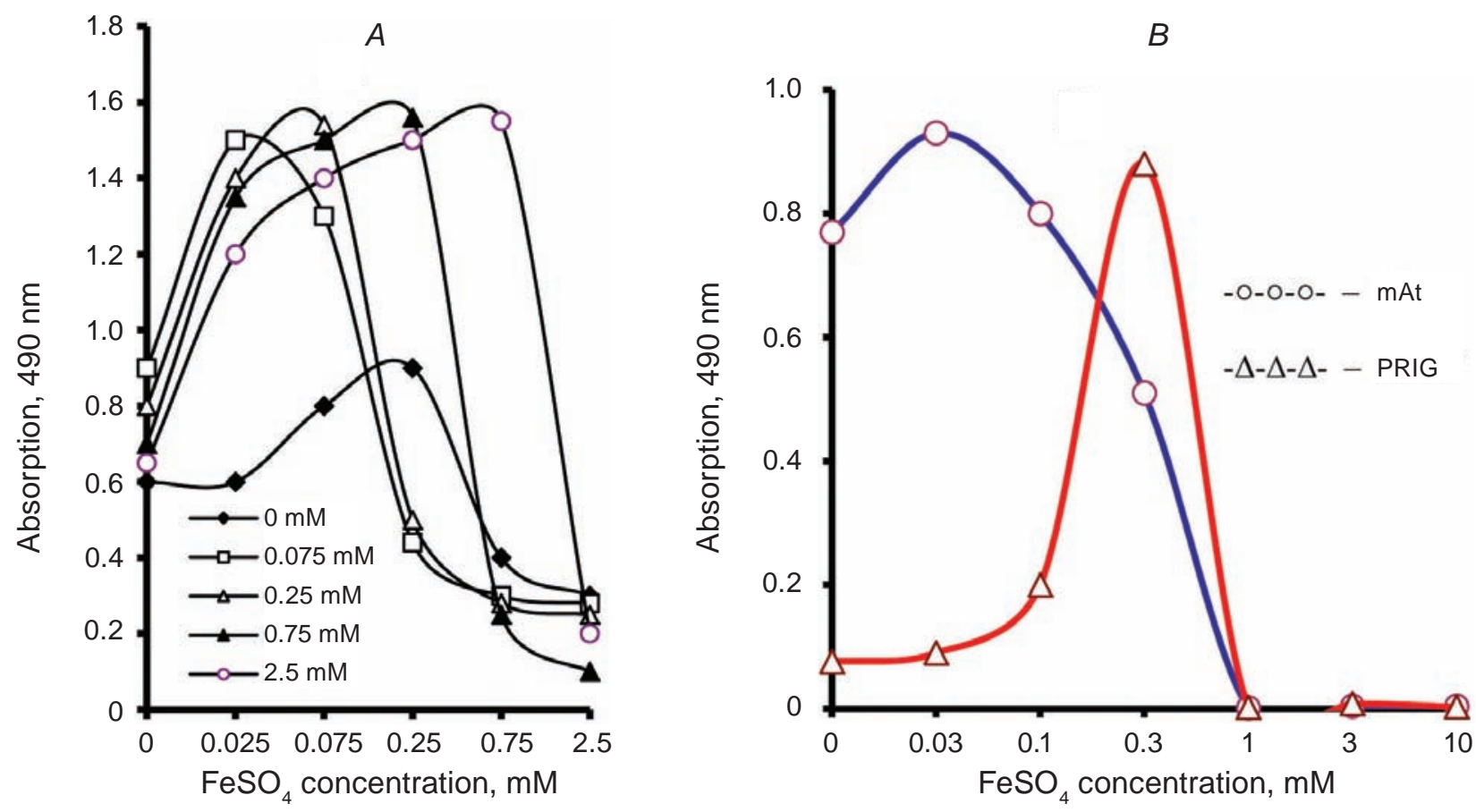

Fig. 6. Effect of EDTA and $\mathrm{FeSO}_{4}$ mixture of various concentrations on ability of serum immunoglobulins to transform into PRIG (A) and induction of transformation of monoclonal antibodies (B) into PRIG accompanied by the decrease of $m A b$ activity and appearance of the peak of PRIG activity at FeSO ${ }_{4}$ concentration of $0.3 \mathrm{mM}$ 
$A$

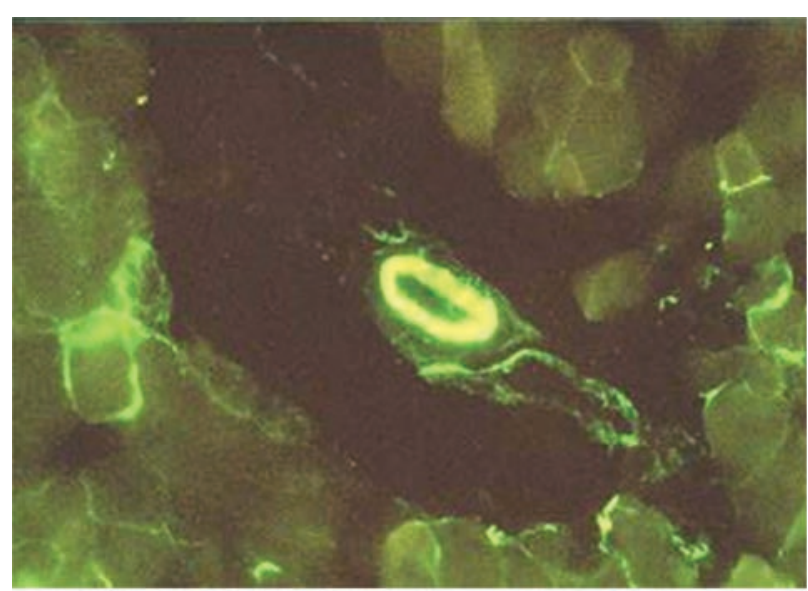

B

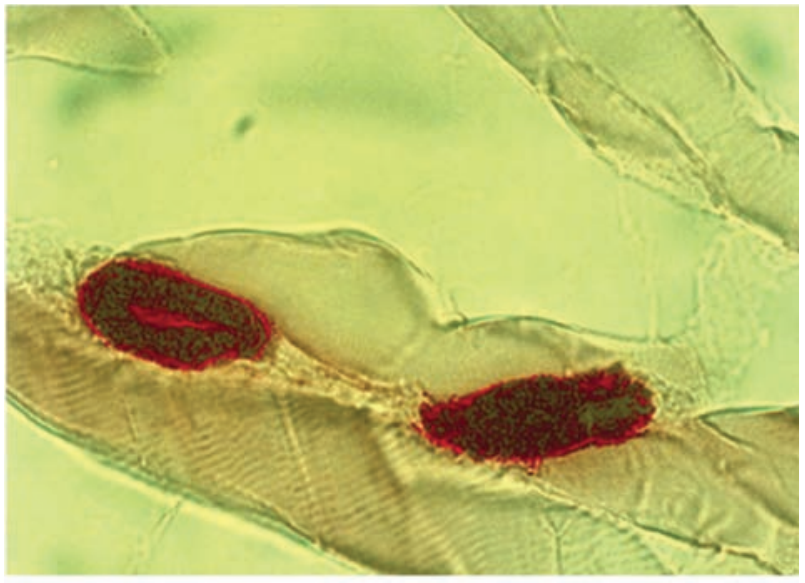

Fig. 7. Ultrathin sections of murine hind limb muscles demonstrating PRIG binding to vascular walls. A - section staining of murine antibodies with fluoroscein-labeled goat anti-Ig $(\times 100$ times); B - section staining with desoxybenzidine $+\mathrm{H}_{2} \mathrm{O}_{2}$ and then with hematoxylin [38] ( $\times 400$ times)

As was said above, we have established [9] that PRIG can efficiently opsonize microorganisms, and, consequently, to intensify phagocytosis of microbes with the cells of reticulo-endothelial system. This means that PRIG, like NAb, may be considered as one of the components of the first line of defense from various infections. Later on we also showed that PRIG have little effect on the level of the humoral immune response of mice to ram erythrocytes, but increase several times the antibody formation in respect of such low-immunogenic antigen as purified tuberculin derivate [14]. Consequently, these data confirm the supposition of protective functions of PRIG at least under some diseases.

On the other hand, since PRIG are able to bind to the vascular walls [34] and to bind a complement, we cannot exclude that PRIG can favor the development of such disease as atherosclerosis. Moreover, when trying to reveal protective functions of PRIG at malignant tumors, we have established that PRIG does not suppress the process of tumor development but stimulates it considerably (Fig. 8) [10]. So, our data indicate that PRIG may play both positive role under infectious diseases and negative one under the development of atherosclerosis and carcinogenesis. These data also state that the further study of PRIG properties and their role in development of numerous diseases is worth more attention.

\section{Avidity of PRIG-antigen interaction}

Since PRIG properties are considerably similar to those of NAb, we can expect that the affinity of PRIG interaction with antigens is also very low as it was usually said about NAb [21-23, 35-40]. Objectively, our first experiments on the estimation of PRIG affinity [6] performed by the method of Friguet et al. (1985) [41] or by other similar methods [42-45] have also indicated low PRIG affinity that, seemingly corresponded with the commonly accepted picture of direct interrelation between low specificity and low affinity of this interaction.

But later, when the mechanisms of PRIG interaction with antigens had become known [29, 30], there doubts arose if such methods may be used to determine PRIG affinity. Being in water medium, protein macromolecule strives to hide its hydrophobic sites inside a molecule, and their hydrophilic sites contacting with water molecules are mainly outside. As soon as just hydrophobic sites on the antigen surface are required for PRIG binding with antigen molecules, then the measuring of affinity of interaction by Friguet et al. method (1985) and similar ones (42-45) will inevitably result in the estimates which will be hundreds and thousands times lower than true values of the given magnitude. This happens for the following reasons. 


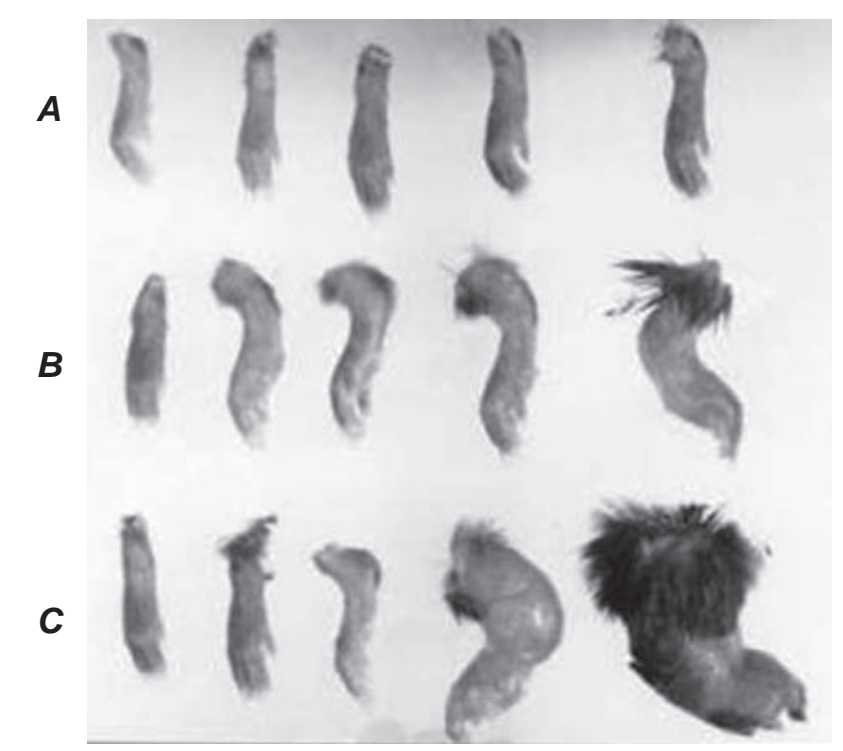

Fig. 8. Influence of PRIG on the development of malignant tumor induced by administration of Lewis carcinoma cells. A - certain dose of Lewis carcinoma cells was injected into the hind limb of mice (control). B-PRIG were first administered to mice intra-peritoneally and then carcinoma cells were injected into limbs. $C$ - carcinoma cells were incubated with PRIG for 30 min at $37^{\circ} \mathrm{C}$, and then they were administered to murine hind limb

It is known that to calculate the affinity of antibodies by the above methods either the concentration of free antibodies or the concentration of their complexes with antigen after reaching the dynamic equilibrium in the mixture antigen-antibody are determined. That allows calculating the affinity constant with the help of the transformed mass action law. There arises a question: are such methods applicable for estimating the affinity of PRIG, which have the affinity for the hydrophobic sites of antigen molecules?

Owing to intramolecular dynamics of protein molecules, the hydrophobic sites may appear on their surface stochastically for a short time; these sites are able to bind to hydrophobic sites of PRIG Fab-domains during the molecules collision. Since only a small part of the total number of protein molecules exposes hydrophobic sites on their surface at the moment, it becomes clear that during affinity estimation the equilibrium constant, calculated as based on estimating the concentration of antigen molecules necessary for blocking a certain part of PRIG, will inevitably be underestimated by several orders.
In addition to above stated note that it is not necessary that the PRIG molecule must collide by its paratope against the molecule of antigen with momentarily exposed hydrophobic site. Much more probably it will be another similar antigen molecule, since in such experiments the concentration of antigen molecules is considerably higher than the concentration of PRIG. Owing to this, PRIG molecule will remain unoccupied by antigen. Consequently, due to such effect the estimate of affinity in PRIG interaction with a given antigen will prove even more underestimated and may be millions of times less than it is in fact. On this basis it becomes evident that the common methods developed for estimating the affinity of the binding of specific antibodies to antigen based on the mass action law are unfit for estimating the PRIG affinity in water medium in respect to soluble antigens, which surface is mainly hydrophilic.

To obtain an experimental support of our conclusion it was necessary to use not the estimation of the efficiency of PRIG blocking by soluble hydrophilic antigen but quite other approaches. One of the approaches is the estimation of the dissociation rate of specific antibodies or PRIG bound to the antigen adsorbed on the plate. Since the reaction of antibodies or PRIG with antigens is reversible, then the antibodies, being in a complex with PRIG immobilized by antigen or specific antibodies, can dissociate to the surrounding solution, and this dissociation rate should be the higher the lower is the avidity of the bond between the above reagents.

In the case that the affinity and avidity of interaction of a certain antibody with adsorbed antigen is relatively high (e.g., affinity is $1.0 \times 10^{8} \mathrm{M}^{-1}$ and above), the number of antibodies which dissociated from the immobilized antigen, when they reach the equilibrium state in this system, will be so small, that it will be impossible to fix this process even with the help of such highly sensitive method as ELISA. This is evidenced both by the theoretical calculations and by the results of our experiments [46].

However if solution of the same antigen which was immobilized on a solid-phase carrier is used as an eluting solution, this process may be intensified many times, which allows to reveal the elution of antibodies in a number of ways. We have objectively found that the incubation of ovalbumin solution in the holes of plates (ovalbumin being firstly immobilized on these plates, and mAb being adsorbed on 

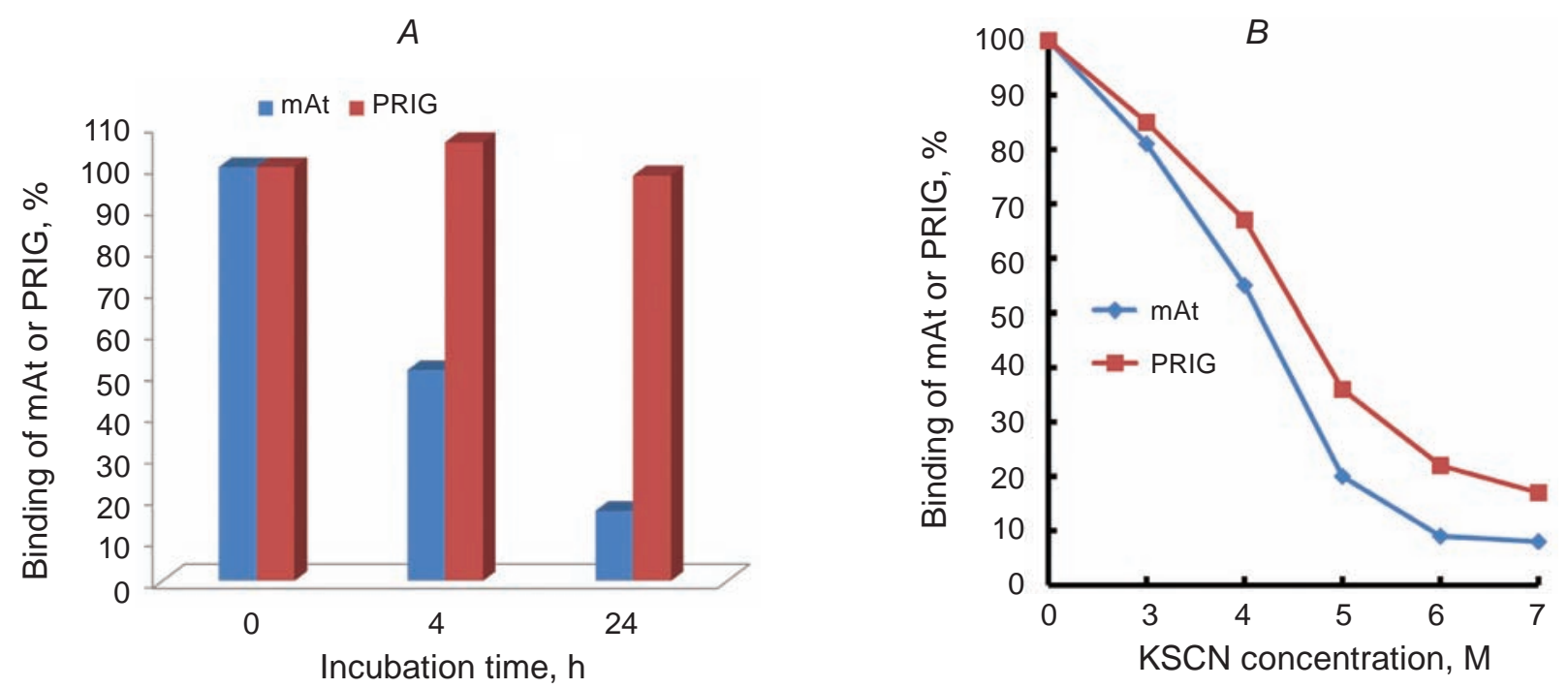

Fig. 9. A - mAb dissociation and full absence of PRIG dissociation from ovalbumin adsorbed on the plate under the effect of ovalbumin solution ( $36 \mathrm{mg} / \mathrm{ml}) ; B$ - dissociation of $\mathrm{mAb}$ or PRIG which were preliminarily bound to antigen immobilized on the plate under the effect of KSCN solutions of different molarity (during 20 min at room temperature)

it) led to rather significant elution of already bound highly affine antibodies (Fig. 9, A). At the same time the same antigen solution did not induce the dissociation of PRIG bound to ovalbumin. These results evidence that the avidity of PRIG binding to the given antibody is, at least, no less than that of the specific $\mathrm{mAb}$ and, possibly, even higher.

One more method which allows us to compare the binding avidity of specific antibodies and PRIG is the method of desorption of antibodies or PRIG previously adsorbed on antigen with the help of concentrated solutions of chaotropic ions, for example, 3.0-4.0 M KSCN solution. In this connection we made an attempt to use this approach to compare the avidity of $\mathrm{mAb}$ or PRIG interaction with ovalbumin or horse myoglobin adsorbed on the plate.

It was established [46] that incubation of $\mathrm{KSCN}$ solution in the holes of the plate (antigen was previously immobilized on it and specific $\mathrm{mAb}$ or PRIG were then bound to it) leads to the efficient elution of both bound $\mathrm{mAb}$ and PRIG. Therewith KSCN solutions caused dissociation of about $80 \%$ $\mathrm{mAb}$ during $20 \mathrm{~min}$ at room temperature, while the same KSCN solutions also caused dissociation of PRIG from immobilized ovalbumin, but the effect was somewhat weaker than under the dissociation of highly affine $\mathrm{mAb}$ (Fig. 9, B). Thus these data also testify that PRIG avidity is not a bit lower than the avidity of highly affine antibodies.
It is significant that we obtained the similar data using both PRIG produced artificially, i.e., by transformation of specific $\mathrm{mAb}$ with the help of $\mathrm{KSCN}$, and in the case when intact PRIG from human and murine sera were used in experiments. This confirms our previous conclusion about similarity or even identity of "artificial" (or induced) PRIG and "natural" (or intact) PRIG.

Thus, the obtained data allow the following fact to be considered as established: PRIG interact with antigens with very high avidity, which is at least highly competitive with avidity of specific antibodies and, maybe, even exceeds it. Hence, the previous opinion on extremely low affinity and, consequently, low avidity of PRIG [47] was wrong.

\section{Differences between PRIG and NAb}

As soon as the so-called natural antibodies (NAb), which possessed relatively low specificity to corresponding antigens and were also able to enter in cross-reaction with unallied antigens [15-20] were previously described in literature, we face the question whether PRIG detected by us are identical to NAb. Our first attempts to estimate the affinity of PRIG binding to antigens in experiments have also shown that the obtained values of the affinity constant are rather low [48]. These data have reinforced our suspicions as to the fact that PRIG and NAb may be very much similar and even identical. If this had 
been so, the effect of considerable increase of PRIG activity after the treatment of solution of supposed $\mathrm{NAb}$ with the help of $\mathrm{KSCN}$ or its acidification to $\mathrm{pH}$ 2.0-2.5 could have been explained by unblocking of $\mathrm{NAb}$ which had been blocked earlier by some serum antigens as a result of low specificity of NAb.

But as was said above, we established later that PRIG activation is not connected with the unblocking of serum antibodies which existed before. Furthermore, the above mentioned analysis of the mechanism of PRIG interaction with antigens has led to the conclusion that the methods, which were mainly used to estimate affinity of specific antibodies to corresponding antigens, do not fit for estimating the affinity of PRIG unspecific binding to antigens [46], and, consequently, PRIG affinity may be much higher than it was considered before. The experiments have completely confirmed this conclusion and permitted establishing that the avidity of PRIG interaction with antigens is really thousands of times higher, than the avidity of NAb binding. This fact indicates that PRIG and NAb are not one and the same substance, and they may be identified with the help of the above test. We have earlier offered some tests, which permit differentiating between PRIG and specific antibodies [48].

Beside that, we have established that PRIG and $\mathrm{NAb}$ differ in a number of properties which may be also used for identification of the given substances. As was said before, PRIG may be considered practically unspecific, while NAb do possess certain specificity, though a noticeable cross reactivity to some antigens is estimated sometimes. Besides, various physicochemical factors or reagents affect the NAb and PRIG binding to antigens in different ways. All these differences are summarized in the table.

Taking into account the above-listed data, it may be concluded that the effectors properties of molecules depending on Fc-domains (such as opsonization of microbes, staphylococcus protein $\mathrm{A}$ fixation, complement binding) in PRIG and in specific antibodies are analogous or identical. On the other hand, the mechanisms of specific antibodies and PRIG binding to antigens, depending on Fabdomains of molecules, have essential differences. Since NAb are really specific antibodies, though they possess low specificity and has an ability to cross-reaction with some unallied antigens, the above differences allow to conclude that PRIG and $\mathrm{NAb}$ are different substances. These differences permit not only discriminating NAb and PRIG, but also to make a conclusion that NAb and PRIG can probably perform not the same biological functions in the organism.

\section{Changes in PRIG activity with age}

Taking into account the fact that PRIG possess the properties different from those of specific antibodies, as well as the fact that today's role of PRIG in organism protection under various diseases or different physiological conditions of the organism remains unknown, we tried to estimate PRIG activity in human sera depending on the age of people. Obviously, to perform such research we have to distinguish between immunoglobulins (which belong to PRIG) and immunoglobulins being natural antibodies, which are able to bind with low affinity to corresponding antigens. Since a method, which allows

Effect of various factors on reaction of interaction of specific antibodies or PRIG with antigens

\begin{tabular}{lcc}
\hline \multicolumn{1}{c|}{ Characteristic } & Low-specific antibodies & PRIG \\
\hline Specificity & yes & no \\
Temperature dependence & low & high \\
Tween 20 & does not affect & suppresses \\
ANS & has little effect & suppresses \\
Lisozyme & does not affect & stimulates \\
Protamine & does not affect & stimulates \\
Avidity & low & high \\
Opsonization of microbes & yes & yes \\
Binding of Staphylococcus protein A & yes & yes \\
Complement fixation & yes & yes \\
\hline
\end{tabular}


distinguishing between PRIG and NAb, had been proposed in one of our last works [46, 48], we succeeded to execute this work.

The basic idea of this method is the use of serum albumin of the same animal (whose PRIG level is to be determined) as the antigen for detecting PRIG. That was made because, as a rule, serum does not contain natural antibodies to its own serum albumin. Another important factor for determining PRIG is the use of special conditions, in which PRIG activity, as we have revealed before [48], considerably increases, that is the titration of PRIG in buffered physiological solution of $\mathrm{NaCl}$ containing $0.05 \%$ of Tween 20 and protamin $(0.1 \mathrm{mg} / \mathrm{ml})$.

The titration curves of IgG PRIG in the sera of five practically healthy young (below 25 years) or five elderly (about 70 years) people are presented in Fig. 10, A. As is seen on the figure, the activity indices of serum IgG PRIG in elderly people exceed those in young adult people. If we calculate the average levels of serum IgG PRIG activity in these two groups of people (Fig. 10, B), the titers in elderly people are about 3-4 times higher than in the young people. Since (according to literature data [49-51]) the concentration of IgG immunoglobulins may increase with age (by about 5-15\%), but considerably less than the found increase of activity of serum IgG

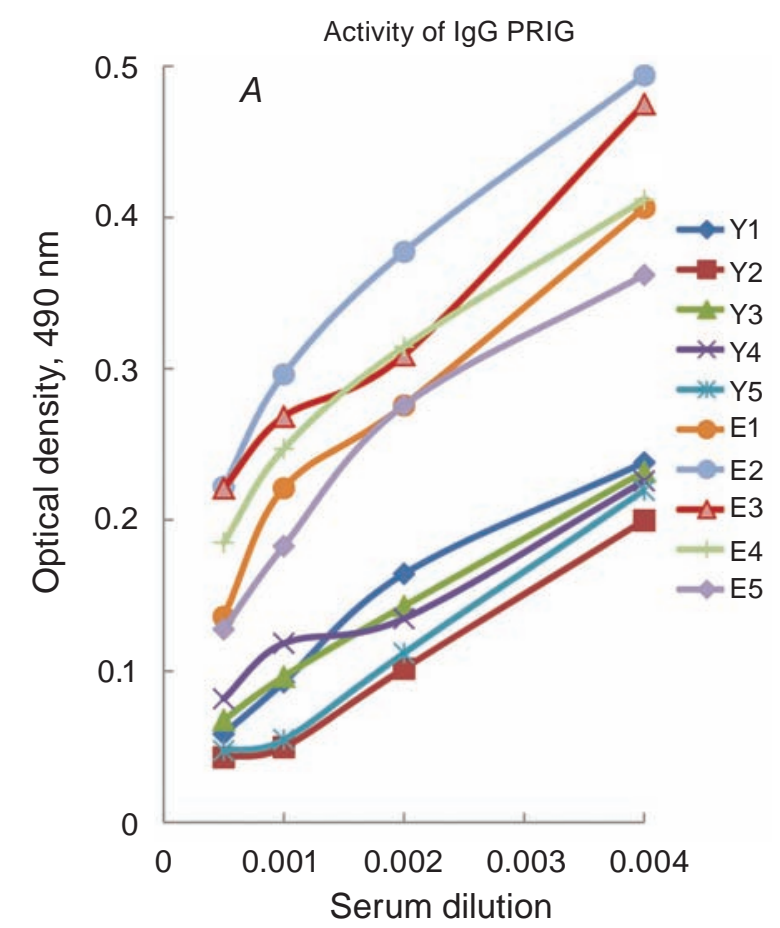

PRIG [11], the data estimated by us evidence that specific activity of IgG PRIG per unit of concentration of serum immunoglobulins noticeably increases with age.

In contrast to considerable increase of the titers of serum IgG PRIG of people the activity of IgM PRIG in sera of the same persons in our experiments did not increase with age, but varied considerably in magnitude, therewith in some elderly persons it was even lower than in some young people (Fig. 11, A). In this connection it may be concluded that the regularities found by us in respect of activity of serum IgG PRIG are not observed regarding the average level of serum IgM PRIG (Fig. 11, B), and that the level of serum IgM PRIG depends to a greater degree on individual peculiarities of immune system of a subject.

Almost the same conclusions can be made in respect of the estimated change in activity of serum IgA PRIG with age (Fig. 12, $A$ ). As well as the activity of serum IgM PRIG, which is apparently proportional to concentration of these molecules in blood sera, activity of serum IgA PRIG of people is considerably more variable as compared to activity of serum IgG PRIG [11]. At the same time, the average activity of serum IgA PRIG still inconsiderably increases in elderly people (Fig. 12, B) as compared to

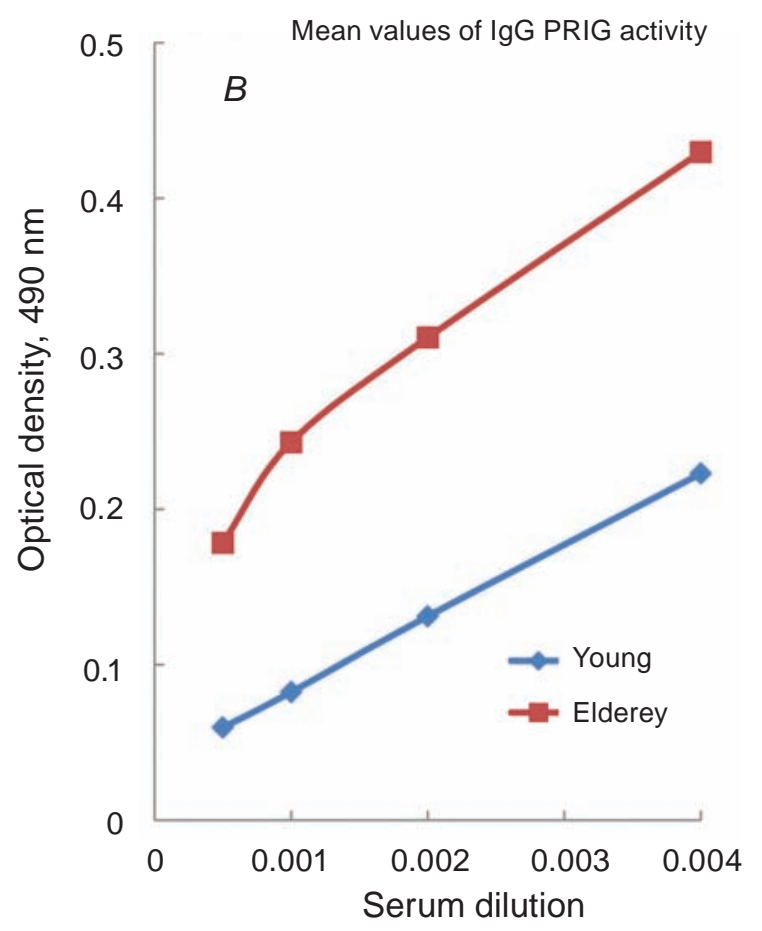

Fig. 10. The titration curves of five sera of young (Y) and five sera of elderly (E) people (A) on the content of IgG PRIG as well as mean values of obtained magnitudes (B) 

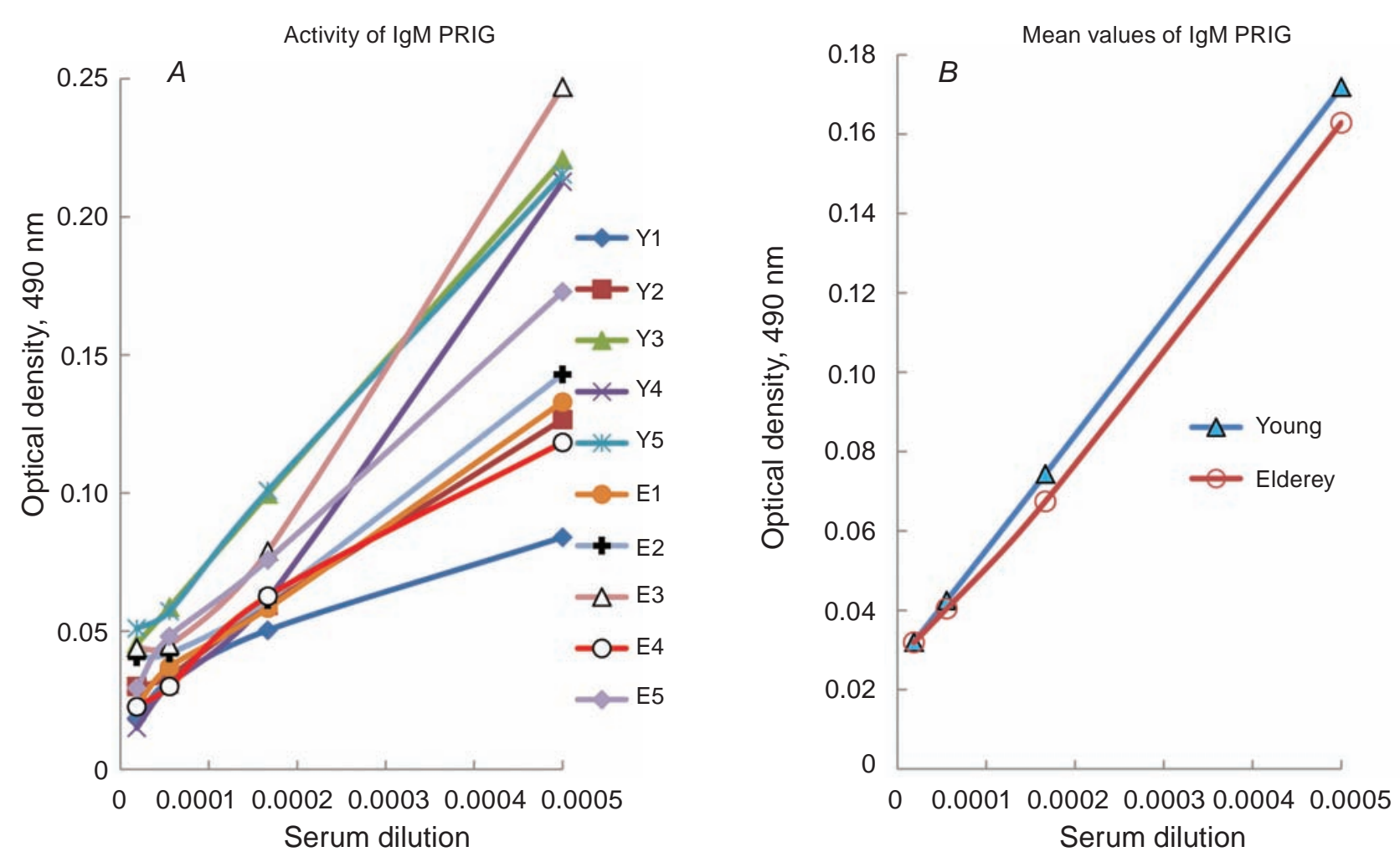

Fig. 11. Titration curves of five sera of young $(Y)$ and five sera of elderly (E) people (A) on the content of IgM PRIG, as well as mean values of obtained magnitudes (B)

young people, though this change is not so noticeable as the activity of serum IgG PRIG.

Thus, the data obtained indicate that the activity of IgG PRIG may vary with age mainly towards the increase, at that the most noticeable change being observed in activity of IgG PRIG which increases 3-4 times with the increase of age from 25 to 70 . The activity of serum IgM and IgA PRIG in the organism varies much more than the activity of IgG PRIG, and the increase of their activity with age either is absent or at least is not so noticeably expressed. The established [11] age changes in the activity of people's PRIG with age, belonging to different classes of immunoglobulins, may evidence both for the immune system degradation with age and probably for an important functional role of these immunoglobulins which still has to be studied. 

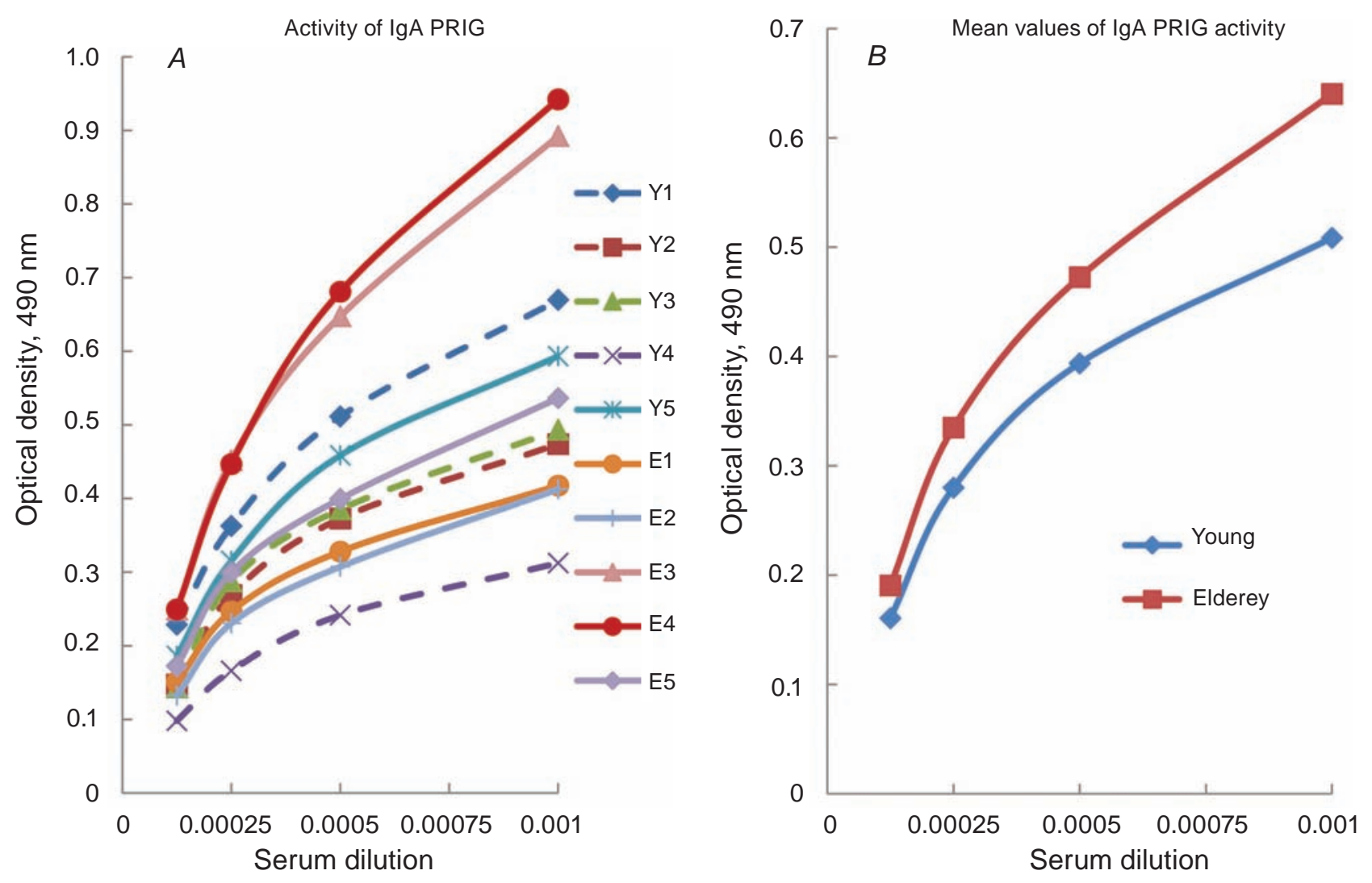

Fig. 12. Titration curves of five sera of young (Y) and five sera of elderly (E) people (A) on the content of IgA PRIG, as well as mean values of obtained magnitudes (B) 


\section{БІОЛОГІЧНІ ТА ІМУНОХІМІЧНІ ВЛАСТИВОСТІ ПОЛІРЕАКТИВНИХ ІМУНОГЛОБУЛІНІВ}

\author{
С. П. Бобровник, М. О. Демченко, \\ С. В. Комісаренко
}

Інститут біохімії ім. О. В. Палладіна

НАН України, Київ;

e-mail: s-bobrov@bk.ru

Невідомий раніше феномен набутої поліреактивності сироваткових імуноглобулінів, які було оброблено концентрованими розчинами хаотропних іонів, таких як $\mathrm{KSCN}(3,0-$ $5,0 \mathrm{M})$, а також низьких/високих $\mathrm{pH}(\mathrm{pH} 2,2-3,0 /$ $\mathrm{pH}$ 11,0-12,0) або температурою до $58-60{ }^{\circ} \mathrm{C}$, вперше було описано нами в 1990 р. Значно пізніше (через одинадцять років) схожі дані було опубліковано J. P. Bouvet зі співавт. (2001р.), котрі повністю підтвердили наші результати відносно впливу хаотропних іонів або різкого зсуву $\mathrm{pH}$ на підвищення поліреактивних властивостей сироваткових імуноглобулінів. Наші дослідження (1993, 1995, 1998 рр.) властивостей поліреактивних імуноглобулінов (ПРІГ) показали, що механізм їх неспецифічної взаємодії 3 антигенами значно різниться від механізму зв'язування специфічних антитіл із відповідними антигенами. Пізніше нами було показано, що підвищення активності ПРІГ може бути індуковано in vivo (1999 р.), а також, що ПРІГ є одним із компонентів інтактних сироваток людини і тварин, а це означає, не виключено, що вони можуть виконувати відповідні біологічні функції. Дослідження впливу ПРІГ на такі процеси, як фагоцитоз мікробів або розвиток злоякісних пухлин (S. A. Bobrovnik зі співавт., 1995, 1998 рр.) вказує на те, що ПРІГ можуть грати відповідну роль у захисті організму від інфекцій або за розвитку різноманітних патологічних процесів. Нещодавно нами було також установлено (С. П. Бобровник зі співавт., 2014 р.), що 3 віком концентрація сироваткових IgG ПРІГ людини істотно зростає. Ці дані вказують на важливість подальших досліджень імунохімічних властивостей ПРІГ і біологічної ролі їх у захисті організму або в разі розвитку різноманітних захворювань.

К л ю ч о в і с л о в а: поліреактивні імуноглобуліни, натуральні антитіла, антигени, специфічність, афінність, авідність.

\section{БИОЛОГИЧЕСКИЕ И ИММУНОХИМИЧЕСКИЕ ПОЛИРЕАКТИВНЫЕ ИММУНОГЛОБУЛИНЫ}

\author{
С. А. Бобровник, М. А. Демченко, \\ C. В. Комисаренко
}
Институт биохимии им. А. В. Палладина НАН Украины, Киев; e-mail: s-bobrov@bk.ru

Неизвестный ранее феномен приобретённой полиреактивности сывороточных иммуноглобулинов, которые были подвергнуты воздействию концентрированных растворов хаотропных ионов, таких как $\mathrm{KSCN}(3,0-5,0$ M), а также низких/высоких рН (pH 2,2-3,0/pH 11,0-12,0) или же нагреванию до $58-60{ }^{\circ} \mathrm{C}$, был впервые описан нами в 1990 г. Значительно позже (одиннадцать лет спустя) сходные данные были опубликованы и J. P. Bouvet с соавтр. (2001), которые полностью подтвердили наши результаты относительно влияния хаотропных ионов или резкого сдвига pH на усиление полиреактивных свойств сывороточных иммуноглобулинов. Наши исследования (1993, 1995, 1998 г.) свойств полиреактивных иммуноглобулинов (ПРИГ) показали, что механизм их неспецифического взаимодействия с антигенами значительно отличается от механизма связывания специфичных антител с соответствующими антигенами. Позже нами было показано, что повышение активности ПРИГ может быть индуцировано in vivo (1999 г.), а также, что ПРИГ являются одним из компонентов интактных сывороток человека и животных, а значит, не исключено, что они могут выполнять определённые биологические функции. Исследование влияния ПРИГ на такие процессы, как фагоцитоз микробов или же развитие злокачественных опухолей (S. A. Bobrovnik с соавтр., 1995, 1998) указывает на то, что ПРИГ могут играть определенную роль в защите организма от инфекций или при развитии различных патологических процессов. Недавно нами было также установлено (С. А. Бобровник с соавтр., 2014), что с возрастом концентрация сывороточных $\operatorname{IgG}$ ПРИГ человека существенно возрастает. Эти данные указывают на важность дальнейших исследований иммунохимических свойств ПРИГ и их биологической роли в развитии разнообразных заболеваний. 
Кл ю че вы е с слов а: полиреактивные иммуноглобулины, натуральные антитела, антигены, специфичность, аффинность, авидность.

\section{References}

1. Bobrovnik S. A., Liashchenko K. P., Komisarenko S. V. Polyspecific antibodies and their activation. Proc. National Acad. Ukraine. 1990;(6):71-74. (In Russian).

2. Bobrovnik S. A. Activation of "silent" antibodies and their interaction with antigens. Ukr. Biokhim. Zhurn. 1990;62(5):86-89. (In Russian).

3. Bouvet J. P., Stahl D., Rose S., Quan C.P., Kazatchkine M. D., Kaveri S. V. Induction of natural autoantibody activity following treatment of human immunoglobulin with dissociating agents. J. Autoimmun. 2001;16(2):163-172.

4. Bouvet J.P., Quan C.P., Dighiero G. Polyreactivity is not an artifact. J. Immunol. Methods. 2001;254(1-2):199-201.

5. Bobrovnik S. A., Marinets A. V. Properties of polyreactive immunoglobulins. Ukr. Biokhim. Zhurn. 1993;65(5):21-26. (In Russian).

6. Bobrovnik S. A. Polyreactive immunoglobulins: molecular properties and functions. Comments Mol. Cel. Biophys. 1999;9:323-356.

7. Bobrovnik S. A. Dynamics of the interaction of polyreactive immunoglobulins with immobilized antigens. Ukr. Biokhim. Zhurn. 1998;70(6):135-143.

8. Bobrovnik S. A. Mechanisms for increasing the activity of polyreactive immunoglobulins in vivo. Ukr. Biokhim. Zhurn. 1999;71(3):129-135. (In Russian)

9. Bobrovnik S. A., Veremeenko E. Yu., Petrova Yu. I., Komisarenko S. V. Evaluation of phagocytic activity of peritoneal cells with flow cytofluorimetry. Proc. National Acad. Ukraine. 1995;(11):139-142. (In Russian).

10. Bobrovnik S. A., Lavrenchuk G. I., Benkovska N. P., Chornaya N. E. Influence of polyreactive immunoglobulins on tumor cells prolipheration. Exp. Oncol. 1998;(20):202-207.

11. Bobrovnik S. A., Demchenko M. A., Komisarenko S. V. Age changes of human serum polyreactive immunoglobulins (PRIG) activity. Ukr. Biochem. J. 2014;86(5)151-155. (In Russian).

12. Bobrovnik S. A., Petrova Yu. I., Efetov K. A. Transformation of serum immunoglobulins to polyreactive antibodies. Ukr. Biokhim. Zhurn. 1997;69(3):36-42. (In Russian).

13. Bobrovnik S. A. Transformation of serum immunoglobulins and monoclonal antibodies into polyreactive immunoglobulins. Ukr Biokhim Zhurn. 1997;69(5-6):97-109. (In Russian).

14. Bobrovnik S. A., Efetov K. A., Petrova Yu. I, Komisarenko S. V. Complement-binding and immuno-modulating properties of polyreactive immunoglobulins. Ukr Biokhim Zhurn. 2003;75(3):104-108. (In Russian).

15. Avrameas S., Guilbert B., Dighiero G. Natural antibodies against tubulin, actin myoglobin, thyroglobulin, fetuin, albumin and transferrin are present in normal human sera, and monoclonal immunoglobulins from multiple myeloma and Waldenström's macroglobulinemia may express similar antibody specificities. Ann. Immunol. (Paris). 1981;132C(2):231-236.

16. Guilbert B., Dighiero G., Avrameas S. Naturally occurring antibodies against nine common antigens in human sera. I. Detection, isolation and characterization. J. Immunol. 1982;128(6):27792787.

17. Coutinho A., Kazatchkine M. D., Avrameas S. Natural autoantibodies. Curr. Opin. Immunol. 1995;7(6):812-818.

18. Dighiero G., Guilbert B., Avrameas S. Naturally occurring antibodies against nine common antigens in humans sera. II. High incidence of monoclonal Ig exhibiting antibody activity against actin and tubulin and sharing antibody specificities with natural antibodies. J. Immunol. 1982;128(6):2788-2792.

19. Haspel M. V., Onodera T., Prabhakar B. S., McClintock P. R., Essani K., Ray U. R., Yagihashi S., Notkins A. L. Multiple organreactive monoclonal autoantibodies. Nature. 1983;304(5921):73-76.

20. Satoh J., Prabhakar B. S., Haspel M. V., GinsbergFellner F., Notkins A. L. Human monoclonal autoantibodies that react with multiple endocrine organs. N. Engl. J. Med. 1983;309(4):217-220.

21. Avrameas S. Natural autoantibodies: from 'horror autotoxicus' to 'gnothi seauton'. Immunol. Today. 1991;12(5):154-159.

22. Avrameas S., Ternynck T. The natural autoantibodies system: between hypotheses and facts. Mol. Immunol. 1993;30(12):1133-1142.

23. Notkins A. L. Polyreactivity of antibody molecules. Trends Immunol. 2004;25(4):174-179. 
24. Zhou Z. H., Tzioufas A. G., Notkins A. L. Properties and function of polyreactive antibodies and polyreactive antigen-binding B cells. J. Autoimmun. 2007;29(4):219-228.

25. Dimitrov J. D., Planchais C., Roumenina L. T., Vassilev T. L., Kaveri S. V., Lacroix-Desmazes S. Antibody polyreactivity in health and disease: statu variabilis. J. Immunol. 2013;191(3):993999.

26. Absolom D. R., van Oss C. J. The nature of the antigen-antibody bond and the factors affecting its association and dissociation. CRC Crit. Rev. Immunol. 1986;6(1):1-46.

27. Van Oss C. J. Hydrophobic and hydrophilic interactions in antigen-antibody binding. IJBC. 1987;3:1-8.

28. Van Oss C. J. Nature of specific ligand-receptor bonds, in particular the antigen-antibody bond. J. Immunoassay. 2000;21(2-3):109-142.

29. Bobrovnik S. A. Polyreactive immunoglobulins recognize hydrophobic parts of proteins. Ukr. Biokhim. Zhurn. 2001;73(2):116-122.(In Russian).

30. Bobrovnik S. A. Mechanisms of interaction of polyreactive immunoglobulins and protein antigens. Ukr. Biokhim. Zhurn. 2002;74(2):3744. (In Russian).

31. Halliwell B., Gutteridge J. M. Oxygen toxicity, oxygen radicals, transition metals and disease. Biochem. J. 1984;219(1):1-14.

32. Weiss S. J. The role of superoxide in the destruction of erythrocyte targets by human neutrophils. J. Biol. Chem. 1980;255(20):99129917.

33. Stadtman E. R. Protein oxidation and aging. Science. 1992;257(5074):1220-1224.

34. Bobrovnik S. A. Transformation of specific antibodies to polyreactive immunoglobulins and their binding to blood vessel walls. Ukr. Biokhim. Zhurn. 2002;74(3):133-141. (In Russian)

35. Weiser M. R., Williams J. P., Moore F. D. Jr, Kobzik L., Ma M., Hechtman H. B., Carroll M. C. Reperfusion injury of ischemic skeletal muscle is mediated by natural antibody and complement. J. Exp. Med. 1996;183(5):2343-2348.

36. Carroll M. C., Prodeus A. P. Linkages of innate and adaptive immunity. Curr. Opin. Immunol. 1998;10(1):36-40.

37. Kobzik L., Bredt D.S., Lowenstein C.J., Drazen J., Gaston B., Sugarbaker D., Stamler J. S. Nitric oxide synthase in human and rat lung: immunocytochemical and histochemical localization. Am. J. Respir. Cell. Mol. Biol. 1993;9(4):371-377.

38. Ternynck T., Avrameas S. Murine natural monoclonal autoantibodies: a study of their polyspecificities and their affinities. Immunol. Rev. 1986;94:99-112.

39. Casali P., Notkins A. L. CD5+ B lymphocytes, polyreactive antibodies and the human B-cell repertoire. Immunol. Today. 1989;10(11):364368.

40. Adib-Conquy M., Avrameas S., Ternynck T. Monoclonal $\operatorname{IgG}$ and $\operatorname{IgM}$ autoantibodies obtained after polyclonal activation, show reactivities similar to those of polyclonal natural autoantibodies. Mol. Immunol. 1993;30(2):119127.

41. Friguet B., Chaffotte A. F., Djavadi-Ohaniance L., Goldberg M. E. Measurements of the true affinity constant in solution of antigen-antibody complexes by enzyme-linked immunosorbent assay. J. Immunol. Methods. 1985;77(2):305-319.

42. Stevens F. J. Modification of an ELISA-based procedure for affinity determination: correction necessary for use with bivalent antibody. Mol. Immunol. 1987;24(10):1055-1060.

43. Bobrovnik S. A. Determination of antibody affinity using ELISA. Ukr Biokhim Zhurn. 1999;71(6):90-102. (In Russian).

44. Bobrovnik S. A. Determination of antibody affinity by ELISA. Theory. J. Biochem. Biophys. Methods. 2003;57(3):213-236.

45. Bobrovnik S. A. New capabilities in determining the binding parameters for ligand-receptor interaction. J. Biochem. Biophys. Methods. 2005;65(1):30-44.

46. Bobrovnik S. A. Avidity of polyreactive immunoglobulins. Ukr. Biochem. J. 2014;86(6):183-189. (In Russian).

47. Dimitrov J. D., Planchais C., Roumenina L. T., Vassilev T. L., Kaveri S. V., Lacroix-Desmazes S. Antibody polyreactivity in health and disease: statu variabilis. J. Immunol. 2013;191(3):993999.

48. Bobrovnik S. A., Demchenko M. A., Komisarenko S. V. Interaction peculiarities of polyreactive immunoglobulins and various antigens. Ukr. Biochem. J. 2014;86(1):68-74. (In Russian).

49. Buckley C. E. 3rd, Dorsey F. C. The effect of aging on human serum immunoglobulin 
concentrations. J. Immunol. 1970;105(4):964972.

50. Cassidy J. T., Nordby G. L., Dodge H. J. Biologic variation of human serum immunoglobulin concentrations: sex-age specific effects. J. Chronic. Dis. 1974;27(11-12):507-516.
51. Stoica G., Macarie E., Michiu V., Stoica R. C. Biologic variation of human immunoglobulin concentration. I. Sex-age specific effects on serum levels of IgG, IgA, IgM and IgD. Med. Interne. 1980;18(3):323-332.

Получено 19.02.2015 